\title{
Historical Museums in Israel: Semiotics of Culture
}

\author{
Gabriel Mayer \\ Postgraduate Affiliate, \\ University of Haifa \\ Abba Hushi Blvd. 199 \\ Mount Carmel, Haifa 3498838, Israel \\ mgabri01@campus.haifa.ac.il
}

\begin{abstract}
Tiny by physical size, the State of Israel retains some of the world's most important cultural treasures, along with many other great cultural institutions. Archeological treasures have yielded much information as far as biblical history and have been well adapted to a Zionist narrative by both the Jewish press and international news organizations, such as the New York Times whose archives are replete with reports of Jewish history being dug up by the Jewish people. Once the State of Israel gained independence in 1948, the course was set for the development of historical museums whose discourse would reflect the most significant events in Jewish history, most especially the Holocaust and the state of constant warfare that continues to imbue the cultural consciousness of its citizens. In this paper we outline, through categorization, the various historical museums, which are currently operating. Furthermore, this article hopes to shed some light upon the cultural sensibilities conveyed through these institutions.
\end{abstract}

Keywords: history; museology; Israeli culture; Holocaust; Israeli society

This paper is about Israeli culture, mythology, and collective needs, as formed by and informed through a variety of historical museums. The working assumption is that in a historical museum culture is partially formed and at the same time the culture is influencing the contents and narratives on display inside the museum. It should be clear from the start that the discussion is held about Israeli museums as viewed by a Jewish population and created by and for Jews. Notwithstanding the multifaceted collective of Israeli society, this work is confined to and circumscribed by this demarcation. In the following sections I intend to provide an explanation for this viewpoint from a historical perspective and also provide a framework of what constitutes a historical museum and justify the methodology of its employ. This will be followed 
by a discussion of the main categorical types of historical museums present in Israel, and finally a detailed accounting of specific museums.

\section{Qualifying the discussion:}

Israel was a created as a Jewish state by Jews-although the population varied from the start-and therefore adheres principally to a Jewish perspective from governance to education and judicial and academic venues as well. The May 1948 Declaration of The Establishment of the State of Israel speaks to this quite well. It begins by stating that it is the birthplace of the Jewish People and the origin of the eternal Book of Books-lines 1 through 4-and then asserts a historical justification and perspective. It continues in paragraphs 5-7 addressing the Holocaust as significant event for Jews and then continues with a call for a Jewish populations and settlement, all the while recognizing its non-Jewish populations and neighbors. ${ }^{1}$ Thus justifying this singular perspective, it may be added that many historians have joined the debate regarding Jewish authorship of history especially as regards events particularly affecting Jews such as the Holocaust and non have answered this better than Professor Dan Michman in his book Holocaust Historiography A Jewish Perspective. ${ }^{2}$

In addition, it may be noted that Jewish culture has a long-standing tradition of expressing history through a particular narrative called Zakhor, or as a form of remembrance rather than traditional historiography. ${ }^{3}$ Pierre Nora contends that history competes with memory and opines that critical history would virtually void the usefulness of a museum. ${ }^{4}$ In similar vain

1 (Council 1948) Authorship attributed to Jewish People's Council, and proclaimed at the Tel Aviv Museum on May 14, 1948.

2 (Michman 2003, p. 3; 43-47)

${ }^{3}$ (Yerushalmi 2012) In this succinct and particularly well-known book, Yerushalmi makes the case for Jewish memory in the form of Zakhor as being the most significant formative aspect of the history of Jews.

4 (Nora 1989, pp. 8-9) 
Miriam Hirsch coined the term "postmemory" to describe the product of what has been transmitted to a current generation from the past, thus laying the argument that what is current in a narrative-perhaps especially so in a museum-is a derivation from the past and may not resemble the original facts. Regardless of the academic debate, this current discussion has sufficient latitude to address them all. In fact, Israel's particular history may be amenable to further modification because of the "war footing" nature of its very existence. Founded in the aftermath-but not because-of the Holocaust, a series of wars starting with the War of Independence in 1948, and later the six-day war of 1967 and the troublesome scar left by the 1973 war have necessitated the introduction of a bereavement mentality in the society. Uri Lebel has stated that, "In this institutionalized cultural climate, bereaved parents-of soldiers killed-themselves were treated as high-status, heroic figures. ${ }^{6}$ Thus we may observe a society with a high esteem of historical events affecting the fabric of daily living. These denominators are crucial aspects in the creation of historical museums in Israel and the narrativization that flows from them.

\section{Historical museum: what is it?}

In order to proceed with this examination, a brief definition of the nature of historical museums follows. The International Council of Museums (ICOM) is the standard setter best known worldwide and it has set rigorous definitions for what is to be considered a historical museum. ${ }^{7}$ In general and for the sake of this discussion, historical museums restrict themselves to the display of historical items that are authentic and part of a historiographical account, to the exclusion of artistic or aesthetic materials, and these items are necessarily identified through provenance

\footnotetext{
5 (Hirsch 2012, pp. 105-7)

${ }^{6}$ (Lebel 2011, p. 358)

7 (ICOM 2014) see Organizational chart, functions and operating standards.
} 
and historical records. Thus having identified the museums for this discussion, and utilizing these guidelines a discussion of Israel's historical museums, by category, will be listed next. Historical museum categories in Israel:

The first category to be considered is the Holocaust museum, and the three most prominent institutions are Martef Hashoa, Ghetto Fighters' House and Yad Vashem. It should be noted that Yad Vashem is far more than a museum and is an institution founded for the purpose of Remembrance as set forth in the August 19, 1953 Law of Yad Vashem. ${ }^{8}$ The full purposes of Yad Vashem, as described by its mission statement located on the institution's website is to serve four pillars of Remembrance: Commemoration, Documentation, Research, and Education. ${ }^{9}$ The Chairman of the Directorate, Avner Shalev, has emphasized many times that the institution is not confined to its world famous historical museum, but caries on a full set of functions. ${ }^{10}$ The two other institutions were actually launched into action in the year 1949, thus preceding Yad Vashem. The next category is comprised of a series of locally functioning institutions and is labeled as heritage or "settlement museums." Professor Tamar Katriel of the University of Haifa has written most extensively on the genre and has set forth a series of observations on characteristics that are commonly shared. They are typically found in municipal localities and serve to describe and document the history of the particular city or town. Uniquely localized historical details are purvey the heritage of the locale, and otherwise serve with minimalized relationship vis-a-vis national or international history and, most interesting, the display of history is arrested somewhere in the 1970s. ${ }^{11}$ The Nahariya Municipal Museum, or The Lieberman House, as it is locally known will serve as the discussant of the genre. Finally we have

\footnotetext{
8 (Knesset 1953/5713)

${ }^{9}$ (Yad-Vashem 1993-Current)

10 (Interview: Shalev Aug. 30, 2015)

${ }^{11}$ (Katriel 1993b, a, 1994) and (Katriel 2013b, pasim)
} 
a series of museums centered on wars, military actions and/or battles, along with military establishments and, as is the case of two, jails for Jewish freedom fighters during British ruled Mandated Palestine. All told, there are fourteen such museums, all operated by the Ministry of Defense (MOD) and sometimes referred to as the IDF museums. ${ }^{12}$

\begin{tabular}{lll} 
Museum & City & Phone \\
\cline { 1 - 2 } > Also see: Defense Forces Memorial sites & & \\
Museums Division of the Ministry of Defense (Hebrew) & & \\
Museum of Underground captives - Akko prison & Akko & 04.9911375 \\
Israeli Air Force Museum & Beer-Sheva & 08.9906853 \\
Museum of Navy and Haapala & Haifa & 04.8536249 \\
Museum of Underground captives & Jerusalem & 02.6233166 \\
HaShomer Museum & Kfar Giladi & 04.6941565 \\
Israel Police Museum & Kiryat Ata & 04.8478710 \\
Museum of Jewish Soldier in World War II & Kiryat Ono & 08.9224764 \\
Armored Corps Museum & Latrun & 08.9784315 \\
Goara Museum & Ramot Menashe & 04.9597402 \\
Etzel Museum & Tel Aviv & 03.5253307 \\
Hagana Museum & Tel Aviv & 03.5608624 \\
Lechi Museum & Tel Aviv & 03.6837582 \\
Palmach Museum & Tel Aviv & 03.6436393 \\
Yad Mordechai Museum & Yad-Mordechai & 08.6720559
\end{tabular}

The MOD Museums in Israel

Monuments and memorial sites are omitted in this work, but a brief mention is necessary because they round out the ethos of bereavement and remembrance of fallen soldier citizens. Arguably, some of the museums from this last group double as memorial sites and the

12 (Lomsky-Feder and Ben-Ari 2012) Includes chapters dedicated to the public representation of heroism and war, as well as mythologized narratives as in the case of Masada. 
exhibitions display a paucity of the standard artifacts collections one might expect. However their qualifying them into a group of historical museums becomes more evident, later on when the administrative and archival aspects of the MOD administration are discussed. Some museums, which might be expected in this discussion, have been excluded for practical reasons. The IDF History Museum, located in Tel Aviv, while connected to the Ministry of Defense, stands free of the above-mentioned administrative hierarchy. It was established some years after the conceptualization of the MOD museum group and, as shall be discussed, it was formed after a long lingering dictum of Ben Gurion during the 1950s was finally brought to fruition in 1991. The Ammunition Hill Monument and Museum, which is so emblematic of a particular historical event, The Battle For Jerusalem, is left out partially because it is better known as a monument. In addition, its contents and displays are for the most part performance oriented and thus further distance the gap from the intended definition of historical museums.

The Atlit Detention Center is a uniquely different museum altogether, as it exists on a large complex-all of which is museal space-within which are located multiple buildings of historic significance, an entire ship, and a treasure trove of artifacts and photographs. It is self administered, meaning it has its own structural administrative hierarchy, archival research center, and functions rather independently from the general constraints of governmental oversight, although it does answer to the Ministry of Sports and Culture, with which it has an excellent relationship. The theme of the Atlit Detention center is the Ha'apala or the illegal immigration to Eretz Israel during the British Mandate controlled Palestine epoch of the $20^{\text {th }}$ century 


\section{The Museums:}

This following section offers an in-depth discussion of the museums introduced at the commencement of this paper. My intentions are to give a detailed and broad overview of each facility and attempt to reconstruct the formative stages as they populated and propagated in Israeli culture.

\section{Martef Hashoah:}

This is a facility that has been shaped by its location and by its early founder, Rabbi Shmuel Kahana. Located on Mount Zion, it sits atop a location whose history dates back to biblical times, and indeed it is mentioned more than once: Book of Samuel (2 Samuel 5:7); Psalm 48 composed by the sons of Korah, I.e. Levites as "the northern side of the city of the great king" which is Zion (1 Kings 8:2; 2 Chron. 5:2); Book of Isaiah (60:14) and in the first book of the Maccabees. Munt Zion is the location for the tomb of King David, and while the exact location of the tomb has been controversial in archeological history, the prevailing consensus is that during TE $<$ EndNote $><$ Cite $><$ Author $>$ Kol-Inbar $</$ Author $><$ Year $>2013</$ Year $><$ RecNum $>6$

Dr. Rabbi Shmuel Zanvil Kahana, a unique individual, has been both the founder and its soul and lasting influence. Shmuel Zanvil Kahana was born in 1905, in Warsaw, Poland, the son of one of the great rabbis of Warsaw. Initially, his education was rabbinical followed by attending the University of Liege in Belgium where he received a doctorate in Eastern Studies. Upon returning (Brog 2002, p. 124)Yavne educational networks. Though not well documented, it is believed that he became involved with the Mizrachi, or Religious Zionist, movement. He sought passage to Palestine and left Poland, making his way through Europe and as a result he arrived in Palestine 
in early 1940, shortly after the outbreak of WWII. Upon arrival he became involved with all aspects of Eretz Israel and connected with the Hapoel HaMizrachi, the precursor of the National Religious Party in Israel. His activities in Israel centered on religious education and he was preoccupied with renewal of religious customs-pageantry, festivals, and traditions- from earlier (biblical) times, doing so with success. As the Holocaust raged on, several individuals in Palestine sought as early as 1942 , to establish some memorialization efforts, or commemoration venues for the perishing Jews and communities. Notably, Mordechai Shenhavi, as early as July of 1942 brought forth initial plans that were presented to the Jewish Agency, at which time he also formulated the term Yad Vashem for this function. ${ }^{13}$

Once the new State of Israel was established in 1948, the government sought guidance from the Ministry of Religion for initiating immediate measures for memorialization. From 1948-197 Kahana was a director general of the Ministry of Religious Affairs on behalf of the National Religious Party and he capably utilized the Hatsofeh (the official daily publication of the party) for spreading ideology as well as news; he was thus seen and regarded as a dynamic leader and public figure. His involvement with Mount Zion became official when he was appointed "in charge of the mountain" by the Ministry of Religious Affairs (hence the government). The newly generated enthusiasm and attention given to Mount Zion and David's tomb was a direct result of the state's search for commemorative activities. This role would position him to become heavily involved with Holocaust commemoration, and lead to functions, which later became

13 (Brog 2002) An excellent review of the early efforts to memorialize the Holocaust's victims 
part of Martef Hashoah. ${ }^{14}$ To fully understand the significance of this affair, one must now revisit the modern history of Mount Zion and King David's Tomb.

For some time during the 20th Century King David's Tomb (and Mount Zion) was already established as a place of pilgrimage for religious Jews. Its significance was catapulted into prominence after Jordan captured the Old City quarters during the 1948 War, and violently expulsed the Jewish inhabitants. From this time onward, and until Eats Jerusalem's recapture in 1967, the Jews no longer had access to the Western Wall (Kotel) as well as other significant locations. By default, the rooftop of David's tomb became the only way to gain visual access to any of these places and soon became the focal point of religious observation. Many commemorative ceremonies, along with Jewish festivals and pageants were now centered in this location. It also grew as a site of religious pilgrimage and was the most visited such location in the new State of Israel. ${ }^{15}$

Rabbi Kahana was a visionary, although in today's parlance he might be called an astute PR man. He soon began sending and distributing slabs rocks from Mount Zion to many locations world wide, where they were used as foundation stones for newly built synagogues. Thus a connection was being cultivated between Mount Zion and World Jewry, alongside its significance in Israel. It may be stated that these efforts were responsible for converting David's Tomb and all surrounding environs on Mount Zion into Jewish scared space, thus attributing a far higher level of importance to Mount Zion than the historical geographic mantle it bore

14 (Cohn 2015) Historical background regarding Martef Hashoah has been "fact checked" during my October 13, 2015 interview, in Jerusalem with Nechama Cohn, who is Dr. Rabbi Zanwil Kahana's daughter, a witness to much of what happened, and a scholar in her own right. Interview in her home, Jerusalem.

15 (Bar 2005, pasim) 
before. Some controversy surrounded these efforts, as they ran counter to the secular oriented viewpoint of nationalistic aspirations.

By 1948 , a steady stream of artifacts-such as damaged Torah parchments- and "martyrs' ashes began arriving in Israel, and these were received with much attention and deliberation as to their proper disposition. The most memorable event occurred during June 1949, when Simon Wiesenthal landed in Tel Aviv with a glass coffin, inside which was 31 jars of "martyrs" ashes from the death camps. The Chief Rabbinate, David Ben-Gurion, and various government dignitaries were present to officially receive them and subsequently they lay in state in Tel Aviv, and visited by thousands, after which they were transported to Jerusalem and ceremonially buried in the Sanhedriya Cemetery. Subsequently a public appeal was launched with the goal of collecting other remains-held privately and by groups-and to bury them on Mount Zion in a public ceremony. The July21, 1950 issue of Hatsofeh carried an article proposing the name Martef Hashoah-literally "Holocaust Cellar"-as the site for such a location. As it turned out, an array of ancient buildings left from the Ottoman Empire were located adjacent to David's Tomb and were progressively recruited for the purpose.

Even as relics and artifacts continued to make their way to Israel, to Martef Hashoah and other burgeoning institutions of Holocaust Commemoration, a rather unique phenomenon started to evolve at the site. This was the bringing of commemorative stone slabs to Martef Hashoah, where they began to collect and serve as a focus for members of specific communities to hold commemorative ceremonies on behalf of the perished martyrs and communities. Each slab was descriptive of the specific community with certain inscription that were designed by their donors to an ideal which best described the loss. Over the years, well in excess of 2,000 individual stone slabs accumulated and brought forth a multitude of visitors and 
commemorative function; as usual, specifically designed to suit their survivors' wishes and specifications. ${ }^{16}$ The unique functions and ceremonies held at Martef Hashoah were to continue until the 1967 War, after which the Kotel resumed its singular position in Judaic worship. While the official name of Martef Hashoah was inaugurated in 1950, the Kibbutz Lohamei Haghetaot began implementing its own traditions, as well as the collecting of artifacts and documents, in 1949. This facility would go on to become the Ghetto Fighters' House Museum. With the passage of the Law of Yad Vashem in 1953, the enterprise of memorialization shifted and began to center around Yad Vashem. Rabbi Kahana was keenly aware of all these activities, and sought to make room for the distinctive function of memorialization as a form of lamentation and to develop the sanctity of the martyrs in manner that addressed spiritual heroism. He was cognizant of the distinctions that were to be made between GFH (Ghetto Fighters' House Museum) and Yad Vashem, and even though in the earlier years there was some politically instigated rivalry amongst them, he knew well what the niche was to be for Martef Hashoah.

Following the ascendancy of Yad Vashem to its current pre-eminent position, along with great advances made at GHF in regards to development, educational forays and diversification of activities, the role of Martef Hashoa began to recede. Lack of funding, along with diminishing interest in Mount Zion once the Kotel became re-established as the most sacred holy site for Jews, eroded the prominence of Martef Hashoa, and various states of disrepair further complicated matters. There was always a committed "die-hard" following, consisting mainly of members of the mourning communities, and religious pilgrimages did continue. Rabbi Mordechai Goldstein assumed the helm in the late 1960 s and was a very energetic influence,

16 (Bar 2004, pasim) This article is arguably the most comprehensive review of the founding and activities of Martef Hashoah. 
which helped maintain a reasonable amount of care and staffing. On the other hand, his energies were also directed toward religious education, and he founded several yeshivas, the most prominent being Yeshiva Torahs Yisrael that is located within the Martef Hashoah compound, with some classrooms situated directly above the facility. His sons, also rabbis, continue his work today along with the administration of the both Martef Hashoah and the Yeshiva. But by the turn of the, millennium the facility began an inexorable decline. However, in the past few years, a new team of dedicated individuals began the rehabilitation process. For various communities, groups and individuals-especially the religious communitiesMartef Hashoah maintains the long standing tradition of personal and religious pilgrimages and serves as the connectedness to the lamentation concept, a process that has been at the core of Martef Hashoah's significance. Current visitors are confronted by the somber mood and contents along with the geographic setting. To begin with, the building, along with its siting among the surrounding structures and geographic layout serves as a historical entity in its own right. The bulk of what is exhibited-and would in most historical museums serve as the artifacts collection-consists of several thousand memorial plaques. They represent murdered individuals and perished communities. These very much fit into long-standing Jewish traditions along the lines of Zakhor and Yahrzeit. Artifacts, as expected perhaps in a traditional historical museum, are fewer in number and some lack provenance precisely due to their historic origins. As an example, consider the bars of soap displayed in the general area of the glass coffin and the jars (empty) of ashes brought to Israel in 1948 by Simon Wiesenthal. Much of the contents of this "shipment of artifacts" were contested between Yad Vashem, the Sate of Israel and Martef Hashoah. In the end they were disbursed among them. During an August interview with Avner Shalev, head of the Yad Vashem directorate, he recounted taking a bar of soap [presumably a 
part of the horde] and driving to Tel Aviv University to have it confirmed as indeed not from humans. ${ }^{17}$ But historical records show that the belief that they were from human fat was systematic among Jews. Further research demonstrates that the Nazis propagated the myth in order to instill fear. Michael Berenbaum, Aaron Breitbart, and Andrew Hollinger have written much about this subject. ${ }^{18}$ The fact remains that the soap(s) bars residing in the facility are documentation of what is very much a Holocaust story, albeit a myth. Current activities are focused on researching many of the archival materials that have only recently been located.

\section{Ghetto Fighters' House:}

The Ghetto Fighters House Museum was one of the first two museums in Israel to address the Holocaust, as a topical narrative, founded in 1949; it also coincided with the state of Israel's first official act designating a facility for Holocaust remembrance. However this was not Yad Vashem, as is widely believed, but Martef Hashoah (Holocaust Cellar). ${ }^{19}$ The task was assigned to the Ministry of Religion, who then placed in charge Dr. Rabbi Samuel Zanwil Kahana,${ }^{20}$ designating him as "in charge of Mount Zion" where the facility was and is located. Kahana served as the director general of the Ministry of Religious Affairs between 1948 and 1971 on behalf of the National Religious Party and was responsible for the development of various holy sites in the State of Israel, such as King David's Tomb on Mount Zion and Elijah's

\footnotetext{
${ }_{17}$ (Interview: Shalev Aug. 30, 2015)

18 (Berenbaum 2012, pasim) The author also interviewed Michael Berenbaum on several occasions, giving further insights.

${ }^{19}$ Noted is the historical fact that Mordechai Shenhavi proposed the concept of collective commemoration of victims as early as 1942, and that the Jewish Agency did officially adopt the project in 1945, naming it Yad Vashem (Brog 2002, pp. 3/37-7/37)

${ }^{20}$ Kahana was born in Poland and immigrated to Palestine in 1940, thus departing prior to the exterminations. He was deeply involved in the Holocaust commemoration in the State of Israel (Bar 2005, Passim)
} 
Cave in Haifa. ${ }^{21}$

The Ghetto Fighters' Kibbutz was officially founded during Passover 1949, and during the dedication a commemorative ceremony was held for the Warsaw Ghetto uprising, victims and survivors, all heroes of resistance. Spontaneously, various members brought in memorabilia, ranging from photographs to some objects they were able to hold on to, and these were stored and displayed. Displayed in a shack adjacent to the main commemoration facility this was a "temporary improvised exhibition"22 The building was somewhat remade and in 1951 it was dedicated as the museum building, though for years it was referred to as "The Shack."23

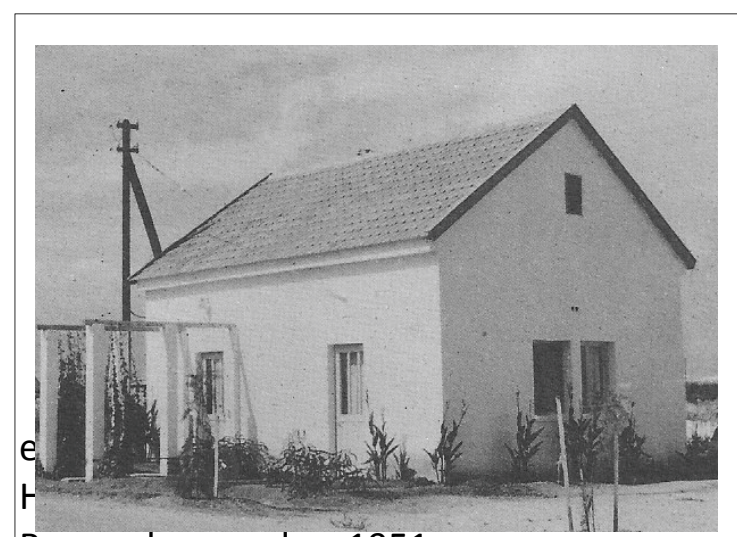

Figure 4.3.1.1 The Shack: this building became known as "The Shack", was dedicated to documentation and commemoration inaugurated at Kibbutz Lohamei Holocaust and Uprising

Remembrance day, 1951.

Courtesy of author G. Mayer

The point remains, that from the earliest of times, the members of the Kibbutz Lohamei Haghetaot and the Ghetto Fighters House Museum were one and the same, with membership formed by survivors and the leadership composed of majority resistance fighters, some from

\footnotetext{
21 (Bar 2005, Passim)

22 (Azaryahu 2000, p.107)

${ }^{23}$ Ibid p.108
} 
the Warsaw Ghetto, others from similar backgrounds, partisans, and armed revolt. ${ }^{24}$ This conferred the ethos of the museum into a narrative of resistance, and as the artifacts were slowly collected, over time, many bore unmistaken reference to this backdrop. Interviews conducted with past and present GFH staff, reveal an evolution of ethos and an attendant role of artifacts. ${ }^{25}$ To begin with, a consistent theme has prevailed:

"The key aspect of the museum narrative is its function as a moral drama."26 This ideology however has been influenced by periodization. In the early years, from 19491970s the most prominent features of the exhibition were directed toward demonstrating heroism and armed resistance; as such, the artifacts brought along by recognized resistance figures were most prominently featured. Then came a period, seen in Israeli culture as well, when resistance came to include any means that preserved Jewish life and culture, now attaching to heroism all efforts to survive and preserve life. During this time, artifacts were still being regarded as supporting the same thematics, however two new influences came along. For one, the museum began accumulating an ever-larger collection of artifacts and now there were more choices to be made, and the display options needed to be revised. Second, the newly recognized themes of resistance ${ }^{27}$ began to include artifacts, which were now more relevant. Simcha Stein was the director of the museum at this time, and describes what took place: "We

24 (Mayer 2016, pasim)

25 A series of interviews between Oct. 2013- May, 2015, included: Anat Bratman-Elhalel (director archives), Evelyn Akherman (director museum and artifacts), Beth Dotan (head international relations and education), Raya Kalisman (education and exhibitions), Dr. Anat Livne (current CEO) and Simcha Stein (CEO 1987-2007).(Interview: Akherman 2014 August, Novemeber, December; 2015 March); (Interview: Bratman-Elhalel 2014); (Interview: Livne 2014 August, October; 2015 February); (Interview: Stein 2014 December 29; 2015 May 6)

${ }^{26}$ (Azaryahu 2000, p.94)

${ }^{27}$ Such "new" themes would include the concept of resistance by simply surviving, or defying regulations and policies, which forbid religious practice, obtaining food, etc. See: Robert Rozett in “Jewish Resistance"(Stone 2004, pp. 342-47) 
had to make choices and create new exhibition space, and wanted to include as many relevant items as possible. So we came up with the concept of the large display case in the central foyer." This display is situated in the 'Yizkor' Hall and is the location for the bulk of the artifacts archives (artifacts displayed). The display includes audio-visual aides and is in two very large wall sized panel sections, which incorporate smaller "cubicles", all covered by opaque glass that is lit up when the viewer pushes the button of that panel or cubicle. "We wanted to engage the audience into a process of investigation and exploration...instead of directing them to what should be viewed, they were now in the position to choose and discover what was behind the display." 28 This hallway, at the time it was installed in 2007, was "state of the art" and provided a very unique approach. However, the changes in museum ethos date back to the late 1970s. The main exhibitions-the permanent and most important-such as the hall with the Treblinka model, and the story of the camps were kept intact, and the model remains a foundational exhibition. Along with these rather durable displays, artifacts at curatorial discretion accompany special exhibitions. However a third, and the newest, approach or ideals, has begun and will in the future spell changes that are still to be determined. The new ideals incorporate moral lessons and universalism, or as some authors have noted, cosmopolitanism as a way to approach the Holocaust. ${ }^{29}$ In their discussion of cosmopolitanism, Levy and Sznaider do point out the criticisms leveled against this approach. The critiques posited by various authors include the dissolution of collective memory, replaced by inauthentic and rootless substitutes and the facts that a global culture answers to no living needs of collective memory. ${ }^{30}$

\section{Yad Vashem:}

28 (Interview: Stein 2014 December 29; 2015 May 6)

${ }^{29}$ (Levy and Sznaider 2004) (Levy and Sznaider 2002)These articles are an excellent introduction to this modern concept and approach to Holocaust universalization.

30 (Levy and Sznaider 2002, p. 89) 
Yad Vashem was a concept or principle dating back to 1942 and was the final product of heated deliberation in the Knesset as well as a concept guided by its first director and at a time Minister of Education, Benzion Dinur. ${ }^{31}$ The formation of Yad Vashem and all its functions are rooted in the "Law of Yad Vashem"32 passed in 1953 by the Knesset. Explicitly stated, is the following wording: under Article 2.2 "to collect, examine and publish testimony ${ }^{33}$ of the disaster and the heroism it called forth, and to bring home its lesson to the people" Thus, in theory, the collection of all materials pertinent to the Holocaust was a mandate. Yet, it took some time to determine the exact functions and purpose of Yad Vashem, with much scholarly debate involved. ${ }^{34}$ While there were some items (artifacts), mostly photographs and documents, which were collected, very little conscious effort was made for creating a collection for a proper museum. Primacy was placed in commemoration and research. There was no historical museum built until 1973, and in the words of one author "The historical museum, with its educational goal, was added almost as an afterthought to the emotional, almost religious pilgrimage." 35 Therefore, in order to address the role of artifacts, one must move forward in time, perhaps twenty years, for a real dialogue to commence. "In 1994, a steering committee at Yad Vashem... began meeting regularly to formulate the concept for a new museum of Holocaust history...from a curatorial viewpoint, we had barely any visual materials with which to

\footnotetext{
31 (Engel 2010, pp. 85-111); (Dinur 1957)

32 (Knesset 1953)

33 By extension, collecting testimony would include materials of many types and this is highlighted in the words of Avner Shalev, written for the introduction of Dorit Harel's book, previously discussed (Harel 2013, pp. 8-15)

34 (Dinur 1957, pasim)In this, the first volume of Yad Vashem Studies, the chairman of the directorate at the time, a noted historian and scholar, Benzion Dinur addresses the many challenges faced regarding scholarship and incorporating the correct approach. It took years for consensus to build, and this was before any significant museum building or collecting efforts were under way.

35 (Rotem 2013, p. 29)
} 
present..." ${ }^{36}$ It was during the 1990s that a serious effort to create a historical museum was instituted and during this time the curatorial staff was augmented by the addition of several remarkably talented personnel, the most outstanding being Haviva Peled-Carmeli. Carmeli came to Yad Vashem in early 1995, just as the first plans were assembled and she was in charge of the artifacts department. ${ }^{37}$ Writing about this period, Avner Shalev-Chairman of Yad Vashemobserves: “This decision set the museum's curators an unusual challenge: to supply a variety of authentic components that make up the exhibition and that include Jewish documentation, particularly visual documentation in as wide a range as possible. We decided to launch efforts of collecting Jewish artifacts, ranging from photographs, objects, artistic work, texts, footage (film) and testimonies by survivors." 38 Shalev adds: "The final principle to be emphasized in describing the curatorial-content structure was the museum's authenticity." 39 According to Silberklang and Tal- both present and directly involved during this crucial period- this represented not only the challenge of collecting, but also what to collect and how, and as expected, there was a learning curve. ${ }^{40}$ Dorit Harel was the museum's chief designer and a large and looming influence over

\footnotetext{
36 (Kol-Inbar 2013, p. 112)

37 Most of what follows in this section was related in a series of interviews, conducted during from May 2014- May2015; interviewees included: David Silberklang (senior historian Yad Vashem and editor-in-chief Yad Vashem Studies), (Kol-Inbar 2013, p. 3); Robert Rozett (head of Yad Vashem libraries), (Interview: Silberklang 2014 August, Septemeber, Ocotber; 2015 March 3; May; June; July);Michael Tal (head of artifacts
} department Yad Vashem)(Interview: Rozett 2014 October, December; 2015 May), Sara Shor (curator of artifacts Yad Vashem),(Interview: Tal 2014 September 9). Silberklang and Rozet were particularly and especially involved in the planning for the new museum, and thus were able to offer key information about the process.

38 (Harel 2013, pp. 8-15)

39 Ibid p.13

40 During July 2014 interviews, Silberklang relates, about Carmeli, that she came to Yad Vashem from a background honed at an Israeli ethnographic museum facility. The transition to collecting and curating Holocaust artifacts was deliberately developed over a period of time. Tal provides examples of how Carmeli worked on long-term relationships with families and institutions, and then was able to return time and time again and augment the historical narratives and bring in more artifacts. 
the narrativization that was decided by the staff, Avner Shalev and the architectural team. ${ }^{41}$ During this period artifacts were collected with a dual purpose of serving the museum design narrative, along with the newly minted desire to show a personal Jewish perspective: "Deciding on the concept of a Jewish perspective on the narrative, led almost necessarily, to positioning the individual as the core of the narrative, and presenting the unfolding of events from a personal viewpoint." ${ }^{42}$

Yehudit Inbar concurs with this viewpoint expressing, "We were, in a way, facing a dead end, because we didn't have a collection of objects at our disposal.... Our questions were answered when Haviva Peled-Carmeli started working at Yad Vashem: her work was devoted mainly to the creation of a collection of objects that would later be exhibited in the museum."43

The collection of artifacts was guided by Carmeli's prescience and sensitivities and in the foreword to her book (on artifacts), published posthumously, she states: "The object, duly preserved, will stay with us during a long time, after it has been created and after those who used it, and its silent testimony will be able to be transmitted to the coming generations. As, those who will find this object will be able, also in the future, to sense the heart that was beating together with the story, the hands that held it and its owner's feelings during the Holocaust; which can be defined as "stones with a human heart" according to the words of the poet Yosi Gamzu. This is the answer we give to those who ask us what the relation is between the collection of objects and the stories behind them with a historical museum." 44 After this brief overview, one can see that the museum as it exists today, was begun in the 1980 s and the current museum was opened up in 2005. While it began as a concept designated

\footnotetext{
${ }^{41}$ Moshe Safdie was the chief architect, while Irit Kochavi was the project manager.

42 Op. cit. p.12

43 (Harel 2013, p. 11)

44 (Peled-Carmeli 2014, p. 16)
} 
for memorialization, it is now an internationally known museum with over 800,000 visitors in 2015.45

\section{Heritage (settlement Museum) Category: Nahariya Municipal Museum-The Lieberman House:}

The museum is located adjacent to a shopping Center-this commercial area built up years after the museum was founded-and it is within walking distance of the city center. Today the museum visitors must make an appointment with Maya Barlev, the current director and she guides visits in a very specific orderly procession so as to provide a historical journey through the formative stages of the city. The narrative emphasizes the Zionist enterprise and is heavy on describing the various Aliyah waves to Eretz Israel. The contents and the disruptions cover, for the most part, the agricultural nature of its founding and how the early settlers progressed from a questionably successful agricultural beginning to a typical Israeli settlement, now a municipality with a city population of $50,000 .{ }^{46}$ There is some reasonable coverage of the 1948 War of Independence but, curiously enough, the Holocaust has one brief mention in a corner wall area. Many of the displays are photographic and some of the objects on display were locally produced yet authentic and thus conforming to the standards of historical museums. The museum narrative abruptly stops in the late 1970 s. The museum is unabashedly influenced by its Jeckes (German) heritage in fact; Jeckes immigrants' families donated many items and photos. One of the sources of many photographs is Andreas Meyer, an internationally known glass artist who created the only recent, post 1970s item, on display: a glass plate made in the early 1990s for the city of Nahariya.

\footnotetext{
45 (Rosenberg 2015, pasim)

46 (Kreppel 2004, pasim)
} 


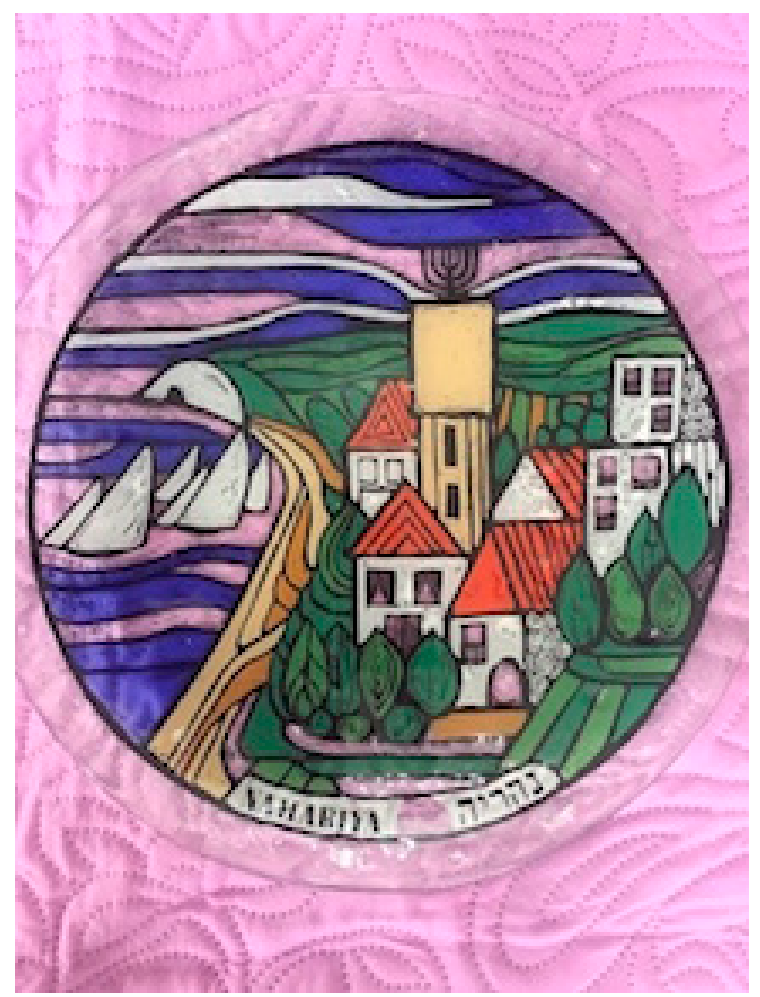

Glass plate produced for municipality by Andreas Meyer, c.1990s

Indeed this museum is in keeping with Tamar Katriel's observation, "Many of these vernacular museums deal directly with aspects of the Zionist agenda and its core values of immigration (in the valorized sense of 'aliyah ), settlement and defense, and were expressly designed to reaffirm the Zionist place-making ethos." ${ }^{47}$

\section{Atlit Detention Center:}

Atlit is a small town on the coast of the Mediterranean. Civilization dating back to the Neolithic age was found as a submerged village off the coast, and as a port and center on the coastal route of the Middle East, it first gained prominence during Crusader times. In the late 1930s the British built a detention camp to house illegal immigrants that were often intercepted on the

47 (KATRIEL 2013a, p. 3) 
seas and it became a teeming and overpopulated entity during the 1940 s. A significant event occurred on the night of Oct. 9, 1945 when the Palmach attacked and broke into Atlit Detention Camp, freeing a large number of Jewish refugees who were then escorted to Haifa accompanied by hundreds of well-comers following in their cars and turning the event into what seemed as a victory procession. The current museal complex occupies nearly 25 acres, very close to the entire original campsite. An array of buildings houses artifacts collections documenting the harsh life endured by Jews. The entrance to the large "reception center" used by the British soldiers has the delousing shower at its entrance-just as it was in its originally functioning stateand serves as a stark reminder of the horrors endured by Jews who, once again, were faced with a shower, the symbolic killing apparatus of the Holocaust.

\section{The MOD Museums:}

To understand the logical rhetoric of these museums, a look at their administrative structure should be emphasized for a start:

The following four agencies report to the Ministry Director-General:

"The MoD Publishing House produces, markets, and distributes books, pamphlets, journals, and government publications, and provides publishing services for all defense-establishment agencies. The IDF Museums Office administers a network of museums that bear witness to Israel's military prowess, document its wars for survival, and commemorate the battle heritage of the IDF and the forces preceding it. The Office establishes and expands the museums and constantly gathers museum material. The Office is composed of a central administration and the following museums: the Eliyahu Golomb Haganah Museum in Tel Aviv, the Amihai Palgin IZL ("Irgun") Museum in Tel Aviv, the Yair Stern Lehi ("Stern Group") Museum in Tel Aviv, an archival repository in Tel Aviv, the Hebrew Battalions House in Moshav Avihayyil, the Ha'apala 
(Clandestine Immigration) and Navy Museum on the outskirts of Haifa, and the Hashomer Museum in Kefar Gil'adi. The Documentation and Research Office gathers and analyzes historically valuable documentation within the civilian defense system, performs and prepares material for historical research, conducts surveys, and instructs civilian defense-system agencies in the collection of historically valuable material.

The IDF and Defense Establishment Archives are the historical archives of the military and civilian defense system; its holdings are considered to be part of the State Archives. The Archives are also the IDF's central records library." 48

The basic ideology and common background of this group of museums stems from the mid 1950s when a group of military leaders-both serving and retired-began to discuss the necessity of elevating military history into public visibility. While the idea an IDF museum was already under discussion, but not advancing, they made plans for a series of museums, which were built around historical scenarios seen as fundamental in the advancement of the Yeshuv and later formation of the State of Israel. Thus they are grouped within a historical framework by dating periods. Aimed at commemorating the early periods of the Yeshuv, from 1909 to 1920 are the Ha'Shomer Museum and the Hgudim Ha'lvri'im (Hebrew Legions) Museum. It is to be noted that the Ha'shomer activists became, in later years, the Hagannah, which went on to the formation of the IDF. The "Undergrounds" refer to the group of museums focused on resistance activism under British rule and include the Stern Museum, the Lehi Museum and the Palmach Museum. Of interest, one should note that it took several years for the acrimony dividing the resistance organizations giving name to these museums to quiet down, and only thereafter was it possible to openly celebrate them as heroes. These museums are roughly falling in the time period

48 (Foreign-Affairs-Ministry 1999) 
between 1920 -1948. The two Underground Prisoner Museums, or as named, Asirei Ha'machtatot- are found in Akko and Jerusalem. The Etzel Museum in Tel Aviv is viewed as bordering on the 9148-time divide. In addition we have the Irgun Museum, the Hebrew Battalions House Museum in Moshav Avihayyil and the Navy Museum on the outskirts of Haifa. Named the Clandestine Immigration and Naval Museum it covers two aspects of maritime history, from illegal immigration and a rag-tag collection of privately procured ships ${ }^{49}$ to the history of the Israel Navy, complete with an actual missile boat, INS Mivtach and the INS Gal, a retired submarine.

It would be far too ambitious to venture into an in-depth discussion of all of these. A closer look at the Palmach museum, through the viewpoint of the architects designing it may provide a clue to the historical complexities engaged in the conceptualization. Rafi Segal was the lead architect in the architectural firm along with his partner Zvi Hecker who in 1992 won the competition launched by the Palmach Veterans Association; the museum building was completed in 1999. 50 Among the ideas discussed we start with the notion that the building had to appear as a monolith in order to demand force, respect, and remind one of a "colossal war bunker." Obliquity as in the sense of anticipation and obliquity seen in war, led to the design of oblique walls. ${ }^{52}$ The embankment of the ground, along with a camouflage like attribution to the groundwork was to serve as a reminder of the unevenness and unpredictability of war terrain. ${ }^{53}$ Throughout the design process he was also keenly aware that one of its main future uses would

49 (Hochstein and Greenfield 1988) An excellent accounting, by Murray Greenfield who was one of the original ship commanders, of the volunteer group of mostly American and English officers of their respected navies who volunteered after the end of WWII in order to bring Holocaust survivors and DP camp denizens to Eretz Yisrael.

50 (Segal 2003)

51 Ibid p.251

52 Ibid p. 253

53 Ibid p.255-6 
be to educate groups of IDF soldiers in the basement lecture rooms. ${ }^{54}$ The detailed conceptualizations seen in the construction of the Palmach Museum building are repeated in each of the museums and further elaborated by the particular site or building's history for each of them. They form a tapestry of Israel's history and cultural past, present and future.

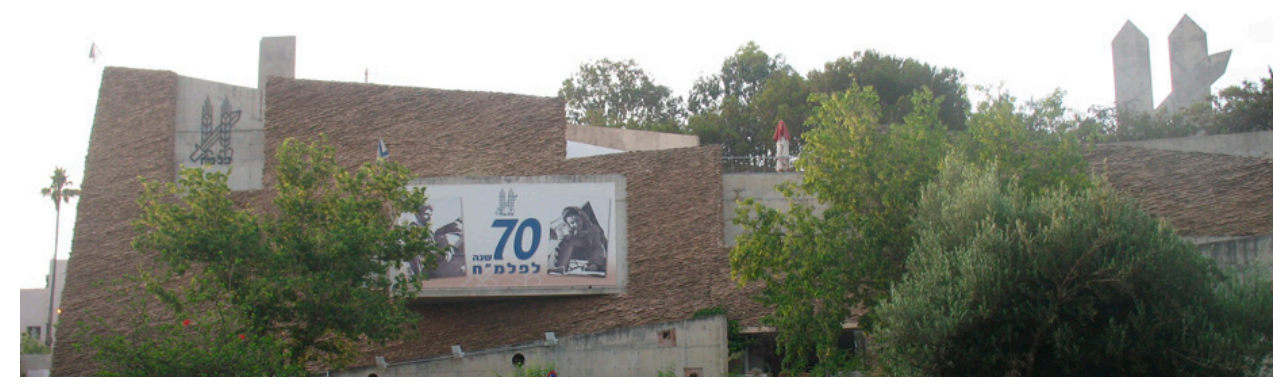

The Palmach Museum

\section{IDF History Museum:}

The museum, located in Tel Aviv, is a latecomer to Israel's military museal hierarchy. While the concept was first proposed, indeed ordered, by Ben-Gurion in the 1950s the only part of his order that was followed faithfully was the collection of all things related to Israeli military history and the IDF. Over a period of years after these orders were given, a huge amount of material went into storage and lay languishing..$^{55}$ Thus when the Beit Ha'osef IDF as it is known in Israel, opened its doors in 1999, it seemingly regurgitated the contents of all that was accumulated and this explains why it is also known as the Collections House Museum. It has been critiqued for being poorly organized and lacking proper curatorial oversight.

\footnotetext{
54 Ibid p.261

55 (Cohen-Mossek 2015, pasim)
} 


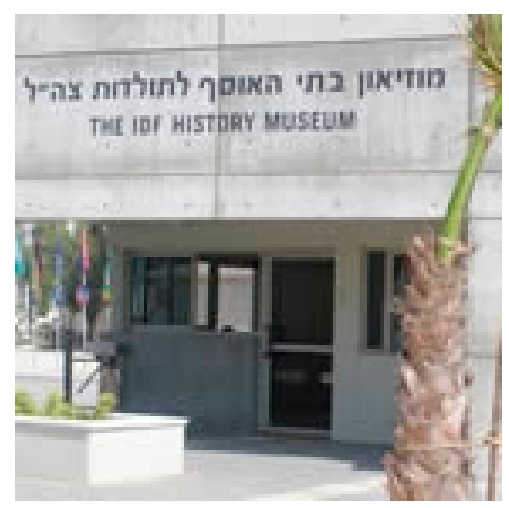

Entrance to IDF History Museum on Koifman Street

\section{Discussion:}

The most difficult issue in combining so much museal material into a coherent discussion lies in the vast collective and collected historical information represented therein. Nonetheless an avenue may be found to do so. Eviatar Zerubavel has noted with regard to the relevance of collective memory to nation-building, “Acquiring a group's memories and thereby identifying with its collective past is part of the process of acquiring any social identity, and familiarizing members with that past is a major part of communities efforts to assimilate them." ${ }^{\prime 56}$ The influence of statism, along with Zionist ideologies, combines to make way for a rational orderliness to the military museums in this discussion. I would posit that the Holocaust museums under discussion along with some of the settlement museums fall in line with a Meta narrative of Jewish history in Israel. While the Holocaust is regarded as an unprecedented ${ }^{57}$ event within a distinctly circumscribed period in Jewish history, its aftermath reverberates through all aspects of World Jewry and definitively connects to Israel, as was noted in the introduction. Tamar Katriel allows us to bridge these events and states, "In clandestine immigration museum, the narrow focus on the theme of survival, on the moment of history,

\footnotetext{
56 (Zerubavel 2012, p. 3)

${ }^{57}$ Curiously, the term "unprecedented" is typically regarded as originating with Yehuda Bauer and Yad Vashem, but the fact is that it was first introduced by Benzion Dinur during a May 1942 talk given in Tel Aviv to a group of teachers (Engel 2010, p. 124).
} 
that stretches through the clandestine immigrants' journey "from shore to shore" fixes their image in the Israeli collective memory within the confines of their Holocaust survivor role."58 And she adds, "Clandestine immigration museums provide a version of the Zionist tale that highlights the story of Jewish victimization as an idiom that legitimizes the center place accorded to the Land of Israel in Jewish life." 59 Viewed collectively from an administrative perspective, the museums discussed in this paper have little to do with one another. Viewed collectively, from a singularly Jewish perspective, they form the transitional and transformative nature of the formation of the State of Israel from the early Aliyot and the Zionist dream to the fierce struggles during the British rule over Palestine and the subsequent War of 1948, which is then followed by a series of wars maintaining Israel on a war footing to the present. The earliest Holocaust museums, which were covered in great detail at the commencement of this work, have an added value in this conceptualization not because of the historical story, but through the opportunity for transitional ideology. Abraham Joshua Herschel said, "For two thousand years we have been a people in mourning. An extensive part of our poetry consists of kinot, lamentations. Yearning and sorrow fill most of our melodies. Yet, we are not alone in our grief." ${ }^{60}$ Now, let's consider the notion that the Mizrahi's identification with the Holocaust was at the best from a distance, while the Ashkenazi were at the center of the maelstrom. Yet if we look at the concept of lamentation as derived from its Biblical origins, then it becomes the one commonality that bridges the gap and informs the two groups in a similar vain. It is plain to see why some religious groups in Israeli society gravitate to a discourse set by Orthodoxy and religious implications in a discussion of the Holocaust.

58 (KATRIEL 2013a, p. 208)

59 Ibid p.209

60 (Heschel 2013, p. 25) 
Coincidentally, it is the wars and militarism, which appeal to the post 1948 generation in the sense of commonality and shared responsibility accompanied by grief and loss. ${ }^{61}$

It follows then that sensibilities formed by a collection of the museums in this discussion do address a particular narrative and it may be traced in time, through the decades, from the early Aliyot, to the underground resistance against the British, to the formation of the new nation State of Israel, while at the same time incorporating the Holocaust narrative of redemption through Zionistic participation in building a new nation, and then continuing under the guidance of the IDF mentality. As a final word, I would acknowledge that the completion of the concepts laid out in this work is far from over. By confining one to historical museums, the "rest of the story" is omitted and would necessitate the discussion of memorials. Part of what is neglected is the war footing ideology prevalent in Israel today and the collective expectation of death and the bereavement mentality. This is a society threatened by existential destructive forces during biblical times, through the centuries, as in the genocidal rampages of the First Crusade in 1099, the Expulsion on March 31, 1492, the pogroms and then the Holocaust, and now facing terrorism on a daily basis in the protracted Palestinian conflict. Moshe Naor talks about the War of 1948 as a concept of Total War. ${ }^{62}$ I would posit that Israel is still in the midst of a total war. These things said, I am well aware of the fact that large segments of Israel's population are woefully neglected in this discourse and certainly left out of the Israeli museal narratives. As one author stated, "Before examining the question of Palestinian invisibility in Israeli museums, it is necessary to look at the stories that Israeli museums actually do tell. These are mostly stories about settlement and the founding of Israel itself, and repatriation of the

61 (Barzani 2016) The author has interviewed several local shopkeepers of Moroccan origin who attribute the Holocaust to G_d's punishment [for sin] and at the same time have expressed unswerving hawkishness as regards the current political climate. 62 (Naor 2008, pasim) 
Jewish community to its biblical homeland. As with most nations, the way that history is told is of utmost importance to their sense of a collective identity. Israel is no exception. But what makes Israel particularly interesting is the fact that its practices of historical construction are so explicitly politically charged." 63 Perhaps even more startling is the omission of the Druze population, whose members have been an integral part of IDF history. ${ }^{64}$ These omissions and questionable issues are beyond the scope of the present work. As a matter of fact, a major shortcoming in Israeli society and in its museums, with the exception of Martef Hashoah, has been to push aside the religious elements in Israel's society as participants in its military history. Yet there are noteworthy researchers and authors whose body of work has added a great deal to our body of knowledge. Professor Judy Baumel of Bar Ilan University (formerly at University of Haifa) pioneered research some two decades ago into Holocaust commemoration at the small community level and described activities occurring via "landsmanschaften" based activities. ${ }^{65}$ Esther Farbstein, an outstanding academic force in chareidi circles, has addressed the spiritual responses to the Holocaust and also produced ground-breaking research analyzing the daily experiences of ordinary Jews as documented by local rabbinical sermons and writings. ${ }^{66}$ In Israel, especially during the first two decades of the new State of Israel, Holocaust Commemoration was largely in the purview of the religious elements. Yet later on a more secular viewpoint prevailed and this then directed the museal discourse that would follow. These gaps remain to be addressed in the future, and one might also ask what the future holds for Israeli museology in the years to come.

\footnotetext{
63 (Petrovato 2006, p. 3).

64 (Firro 1999, pasim) and (Gelber 1995, p. 236-8).

65 (Baumel 1995) and (Baumel 2001).

66 (Farbstein 2007) and (Livneh and Greenberg 2010, Farbstein as Editor).
} 


\section{Bibliography:}

Azaryahu, Maoz \& Donner, Batia. 2000. Beit Lohamei Haghetaot, 1949-1999 50th Jubilee. Israel: Kal Press.

Bar, Doron. 2004. "Re-creating Jewish Sanctity in Jerusalem: Mount Zion and David's Tomb, 1948-67." Journal of Israeli History 23 (2):260-278.

Bar, Doron. 2005. "Holocaust Commemoration in Israel During the 1950s: The Holocaust Cellar on Mount Zion." Jewish social studies 12 (1):16-38.

Barzani, Dudi. 2016. Interview with Dudi Barzani: a small time Mizrahi shopkeeper in Nahariya's plaza. edited by G. Mayer.

Baumel, Judith Tydor. 1995. "“In everlasting memory": Individual and communal Holocaust commemoration in Israel." Israel Affairs 1 (3):146-170.

Baumel, Judith Tydor. 2001. "" In perfect faith": Jewish religious commemoration of the Holocaust." Studies in Religion/Sciences Religieuses 30 (1):5-21.

Berenbaum, Michael. 2012. "What the Survivor and Historian Kknow." The Forward, May 12 2012.

Brog, Mooli. 2002. "In Blessed Memory of a Dream: Mordechai Shenhavi and Initial Holocaust Commemoration Ideas in Palestine, 1942-1945." Yad Vashem Studies 30:297-336.

Cohen-Mossek, M. 2015. "Israel's Military Museums: History Museums or Memorial Monuments?" Ma'arav (Dec. 31, 2015).

Cohn, Nechama. 2015. Interview Nechama Cohn. edited by Gbriel Mayer.

Council, Jewish People's. 1948. THE DECLARATION OF THE ESTABLISHMENT OF THE STATE OF ISRAEL.

Dinur, Benzion. 1957. "Problems Confronting'Yad Vashem'in its Work of Research." Yad Vashem Studies 1:7-30.

Engel, David. 2010. Historians of the Jews and the Holocaust. Stanford, Calif.: Stanford University Press.

Farbstein, Esther. 2007. Hidden in Thunder: Perspectives on Faith, Halachah and Leadership During the Holocaust. Vol. 1: Feldheim Publishers.

Firro, Kais. 1999. The Druzes in the Jewish state: a brief history. Vol. 64: Brill.

Foreign-Affairs-Ministry, Israel Ministry of Defense: 1999 Archives of Israel of. 1999.

"Functions and Structure of the Ministry of Defense." Ministry of Defense: Israel. http://www.mfa.gov.il/mfa/mfa-archive/1999/pages/ministry of defense.aspx.

Gelber, Yoav. 1995. "Druze and Jews in the War of 1948." Middle Eastern Studies 31 (2):229-252.

Harel, Dorit. 2013. Facts and Feelings. Jerusalem, Israel: Yad Vashem.

Heschel, Abraham Joshua. 2013. Israel: An Echo of Eternity: Macmillan.

Hirsch, Marianne. 2012. The generation of postmemory: writing and visual culture after the Holocaust: Columbia University Press.

Hochstein, Joseph M, and Murray S Greenfield. 1988. The Jews' Secret Fleet: Gefen Books.

ICOM. 2014. "Key Concepts of Museology." http://icom.museum/professionalstandards/key-concepts-of-museology/.

Interview: Akherman, Evelina. 2014 August, Novemeber, December; 2015 March. Museum Director and Artifacts GFH. edited by G. Mayer.

Interview: Bratman-Elhalel, Anat. 2014. Head of Archives GFH. edited by G. Mayer.

Interview: Livne, Anat. 2014 August, October; 2015 February. Director GFH. edited by G. Mayer. 
Interview: Rozett, Robert. 2014 October, December; 2015 May. Director of Libraries Yad Vashem. edited by G. Mayer.

Interview: Shalev, Avner. Aug. 30, 2015. "Chairman of the Directorate of Yad Vashem."

Interview: Silberklang, David. 2014 August, Septemeber, Ocotber; 2015 March 3; May; June; July. Senior Historian Yad Vashem. edited by G. Mayer.

Interview: Stein, Simcha. 2014 December 29; 2015 May 6. Director GFH 1996-2008. edited by G. Mayer. GFH.

Interview: Tal, Michael. 2014 September 9. Director Artifacts Department Yad Vashem. edited by G. Mayer.

Katriel, Tamar. 1993a. "“Our future is where our past is:" Studying heritage museums as ideological and performative arenas." Communications Monographs 60 (1):69-75.

Katriel, Tamar. 1993b. "Remaking place: Cultural production in an Israeli pioneer settlement museum." History and Memory:104-135.

Katriel, Tamar. 1994. "Sites of memory: Discourses of the past in Israeli pioneering settlement museums." Quarterly Journal of Speech 80 (1):1-20.

KATRIEL, TAMAR. 2013a. "CHAPTER ONE HOMELAND AND DIASPORA IN ISRAELI VERNACULAR MUSEUMS TAMAR KATRIEL." Memory and Ethnicity: Ethnic Museums in Israel and the Diaspora: 1.

Katriel, Tamar. 2013b. Performing the past: A study of Israeli settlement museums: Routledge.

Knesset. 1953. Martyrs' and Heroes Remembrance (Yad Vasehm) Law 5713-1953. edited by Israel State. Jerusalem Israel.

Knesset. 1953/5713. Martyrs' and Heroes' Remebrance Authority- Law of Yad Vashem. edited by State of Israel.

Kol-Inbar, Yehudit. 2013. "Exhibiting THe Shoah: A Curator's Viewpoint." Post Script 32 (2):1-12.

Kreppel, Kraus. 2004. Lieberman House-Museum of the History of Nahariya.

Lebel, Udi. 2011. "Panopticon of Death: Institutional design of Bereavement." Acta Sociologica 54 (4):351-366.

Levy, Daniel, and Natan Sznaider. 2002. "Memory Unbound The Holocaust and the Formation of Cosmopolitan Memory." European Journal of Social Theory 5 (1):87106.

Levy, Daniel, and Natan Sznaider. 2004. "The institutionalization of cosmopolitan morality: The Holocaust and human rights." Journal of Human Rights 3 (2):143-157.

Livneh, Anat, and Avner Greenberg. 2010. "'The Cry of the Desperate and the Fortitude of the Remaining will Suffice": Commemorative Literature, Documentation and the Study of the Holocaust, 1945-1961." Dapim: Studies on the Holocaust 24 (1):177222.

Lomsky-Feder, Edna, and Eyal Ben-Ari. 2012. Military and Militarism in Israeli Society, The: SUNY Press.

Mayer, G;. 2016. Holocaust Museums: Artifacts Linking History and Culture. Saarbrucken, Germany: Scolars' Press.

Michman, Dan. 2003. "Holocaust historiography: a Jewish perspective: conceptualizations, terminology, approaches and fundamental issues."

Naor, Moshe. 2008. "Israel's 1948 War of Independence as a Total War." Journal of Contemporary History 43 (2):241-257.

Nora, Pierre. 1989. "Between memory and history: Les lieux de mémoire." Representations:7-24. 
Peled-Carmeli, Haviva. 2014. Testigos Silencios. Jerusalem, Israel: Yad Vashem.

Petrovato, J. 2006. "Producing National Identity: Museums, Memory and Collective Thought in Israel." State of Nature (March 26, 2006).

Rosenberg, Yad Vashem; Editor in Chief Iris. 2015. Yad Vashem Annual Report 2015. Jerusalem: Yad Vashem.

Rotem, Stephanie Shosh. 2013. Constructing Memory : Architectural Narratives of Holocaust Museums. Bern ; New York: Peter Lang. still image.

Segal, Rafi. 2003. "The Palmach History Museum, Tel Aviv." The Journal of Architecture 8 (2):251-263.

Stone, Dan. 2004. The historiography of the Holocaust: Palgrave Macmillan.

Yad-Vashem. 1993-Current. "Mission Starement of Yad Vashem." [Descirption of institutional funcions]. http://www.yadvashem.org/yv/en/about/.

Yerushalmi, Yosef Hayim. 2012. Zakhor: Jewish history and Jewish memory: University of Washington Press.

Zerubavel, Eviatar. 2012. Time maps: Collective memory and the social shape of the past: University of Chicago Press.

(C) 2016 by the authors; licensee Preprints, Basel, Switzerland. This article is an open access article distributed under the terms and conditions of the Creative Commons by Attribution (CC-BY) license (http://creativecommons.org/licenses/by/4.0/). 